\title{
MULTI-CRITERIA RANKING OF ORGANIZATIONAL FACTORS AFFECTING THE LEARNING QUALITY OUTCOMES IN ELEMENTARY EDUCATION IN SERBIA
}

\author{
Vladislava EPIFANIĆ(D)1, Snežana UROŠEVIĆ (iD)2, Andrea DOBROSAVLJEVIĆ(D)2, \\ Gordana KOKEZA ${ }^{3}{ }^{3}$, Nikola RADIVOJEVIĆ ${ }^{4} 4^{*}$ \\ ${ }^{1}$ IQ Individual, Novi Sad, Serbia \\ ${ }^{2}$ Technical Faculty in Bor, University of Belgrade, Bor, Serbia \\ ${ }^{3}$ Faculty of Technology and Metallurgy, University of Belgrade, Belgrade, Serbia \\ ${ }^{4}$ Technical College, Kosovska 8, Kragujevac, Serbia
}

Received 03 June 2020; accepted 21 September 2020

\begin{abstract}
The research within this paper is motivated by the opinion that different organizational factors in primary education can have a stronger or weaker impact on the quality of the learning outcome. Organizational factors, criteria analyzed in this paper, are school management, school infrastructure, students' foreknowledge, teacher competencies, curriculum content, student motivation, and the quality of the teaching process. Using SWARA (Step-wise Weight Assessment Ratio Analysis) method of multi-criteria decision-making, the answers of elementary school principals, members of the panel of experts, were processed. The calculation within this method was performed using fuzzy numbers to ensure the reliability of expert evaluations. The results of the applied method, in the form of weighting coefficients of the criteria, indicate that school management has an influence on the selection and building of teachers' competencies while the given competence can indirectly affect the overall success of students through the establishment of an adequate school infrastructure, which affects the knowledge quality. Knowing the factor that has the highest impact enables principals to manage this factor and contribute to enhancing the knowledge quality. This research contributes to raising awareness of the importance of particular organizational factors in elementary education and the need to improve them.
\end{abstract}

Keywords: SWARA method, fuzzy number, organizational factors, quality of learning outcomes, elementary education, school management, teacher competencies.

JEL Classification: I21, D81, D83.

\section{Introduction}

A school is a system consisting of a number of functionally connected elements that make up the subsystems of a given system. The important elements of the school as a system are

*Corresponding author. E-mail: radivojevic034@gmail.com

Copyright (c) 2020 The Author(s). Published by Vilnius Gediminas Technical University

This is an Open Access article distributed under the terms of the Creative Commons Attribution License (http://creativecommons. org/licenses/by/4.0/), which permits unrestricted use, distribution, and reproduction in any medium, provided the original author and source are credited. 
the following: managers, teachers, teaching and students. In order for a school to effectively achieve its planned goals, it is necessary to have an appropriate organization, coordination between all relevant elements and processes, continuous changes in accordance with contemporary tendencies, teamwork, and above all the creation of new and the dissemination of existing knowledge.

The basis for assessing the quality of an educational process is the educational outcome, which include the knowledge, abilities, skills and attitudes of students acquired through formal education at both the elementary and secondary school levels (Fauth et al., 2014). Learning outcomes are the knowledge, skills and competences, in the narrow sense, that a person has acquired through learning and which are demonstrated after learning. The results of the learning process help students see the extent to which they have adopted the foreseen curricula that will enable them to enroll into the next desired level of education.

A review of the available literature showed that organizational factors have a significant impact on the quality of learning outcomes in elementary education and are a framework for sustainability in elementary education. This research recognizes the potential of factors such as managerial skills of principals, school managers, teaching resources, infrastructure, and curriculum management, which highlights Wahyono (2015), then prior knowledge and motivation of students (Lin et al., 2016; Won et al., 2020), and the quality of the teaching process (Asfani et al., 2016), to achieve a certain level of impact on the quality of learning outcomes. While many studies deal with the influence of individual factors on various aspects related to higher education (Haapakorpi, 2011; Ďurišová et al., 2015; Cruickshank, 2017), the influence of these factors as a set should be investigated in more detail in relation to the quality of initial knowledge in elementary education. The research within this paper begins with the observation of factors as a set of organizational factors of influence, but it is also considered that the factors within such a set have a different level of influence. Therefore, there is a need to evaluate the level of influence of individual organizational factors from the set.

School organization, as an institution, is under the purview of human resources, primarily teachers, associates and employees holding strategic positions, i.e., the school principal. Chang et al. (2015) recognize the impact that school principals have on students and the success that students achieve. Accordingly, a research question is formed which reads: "To what extent do organizational factors in elementary education affect the quality of learning outcomes, based on the assessments of primary school principals?"

Therefore, hypothesis H0 is formed: There is no difference in the influence of organizational factors in elementary education on the quality of learning outcomes based on the assessments of elementary school principals.

By testing the set hypothesis and answering the set research question, a base which facilitates the process decision-making and the creation of sustainable solutions within elementary education institutions is created. At the core of this base is the emphasis on organizational factors in elementary education and their potential to influence the quality of knowledge outcomes. In order to achieve better outcomes, it is necessary to strengthen those organizational elements that affect them most and which have thus far not been sufficiently represented. Accordingly, this paper seeks to make a contribution to the theme of improving the quality of learning outcomes in elementary education. 
In this paper, the authors sought to highlight the impact of organizational factors on the quality of learning outcomes in elementary school. The research represents a contribution to solving the subject problems, but also has a practical application as an auxiliary tool for decision-makers, that is, managers and employees of the school. Survey data should inform decision makers to the possibility that the organizational factor has the most significant influence on achieving the desired goal. In this way, decision makers can direct necessary activities that will influence a given factor in order to achieve the planned goals in the most efficient manner.

This research is structured in following manner: a section dedicated to the overview of prevailing literary attitudes and understandings concerning the quality of learning outcomes and organizational factors that may have an influence on it, a methodology section, section of the results of the conducted research, a discussion section and a section of conclusions derived from the research results.

\section{Overview of prevailing literary attitudes and understandings from the field of this research}

Research into the impact of organizational factors on the quality of learning outcomes is a topic addressed by a small number of researchers, while most of the research has primarily concerned itself with the quality of knowledge in secondary schools and higher education institutions. In order to obtain new findings that enable the improvement of the quality of learning outcomes in elementary education, as a knowledge base to which all subsequent ones are upgraded, a brief review of previous research on attitudes regarding the quality of learning outcomes and organizational factors that can influence the quality of learning outcomes is presented.

\subsection{Overview of prevailing attitudes about the quality of learning outcomes}

The period of attending elementary school is very important for acquiring knowledge and certain skills, which necessarily influences the results that students will achieve during their future education. Smiljanić (2013) defines and understands learning as a relatively permanent change in an individual, which is the result of his experiences and is driven by the needs of that individual. Kokeza et al. (2016) find that the dynamics of changes in education are fast and large, and that old models of education evolve into new, more advanced models. The contribution of the study is to raise awareness of the fact that innovation readiness is very important, and that innovation helps businesses achieve higher levels of competitiveness and business success (Abdi et al., 2018; Gerasymchuk, 2018).

Brinson (2015) confirms that different learning outcomes are achieved for students who have adopted the material by traditional methods compared to students who have adopted the material by using modern methods using virtual learning capabilities provided by modern information technologies. A study examining the impact of Lithuanian higher education institutions on the local economy showed that higher education institutions significantly determine the success of the local economy, indicating the importance of the correlation between the quality of higher education and its outcomes (Vaiciukevičiute et al., 2019). 


\subsection{Overview of prevailing attitudes about organizational factors that may influence the quality of learning outcomes}

Overview of prevailing attitudes about organizational factors that may influence the quality of learning outcomes. This paper analyses the importance of strategic management, strategic analysis, planning, selection and strategic change, which represents the framework for sustainability in elementary education, and which are within the purview of the human resources placed in strategic positions. Effective human resource management in elementary education is gaining in importance in all educational institutions, since the knowledge they possess is the most significant resource of such an organization.

Blume et al. (2010), exploring the way of knowledge transfer, i.e., moderators (open and closed, i.e., human resources and information systems), conclude that the importance of human resources as moderators of knowledge transfer is greater than closed systems as moderators. Motivation factors and infrastructural conditions are most important in knowledge transfer.

Organizational factors that influence the quality of learning outcomes are the infra-structural conditions, the quality of elementary school educational outcomes is greatly influenced by teachers and their knowledge and competences, students' backgrounds, students' motivation, school management, and the curriculum.

\subsubsection{School management}

Organizational factor, which is considered one of the key factors of quality, is management. According to Alibabić (2009), management can be viewed according to at least two levels: management of educational activities, i.e., management of the education system and educational institution/organization and management of the educational process, i.e., educational programs and learning projects.

Cheng (1994), Robinson et al. (2008), and Sammons et al. (2011) explore how management-principal is related to school performance (such as school organizational characteristics, teacher performance, and student performance), and concludes that the principal is a key factor which influences school performance. The principal is the person responsible for motivating and mobilizing the intellectual and social potential of the school. A school cannot be successful without a successful principal. Strong leadership is a major factor that can support and encourage teachers, develop clear goals and policies, and achieve teacher participation for better outcomes as well as for their professional development. Strong leadership is associated with high organizational effectiveness, strong organizational culture, a positive principal-teacher relationship, greater participation in decision-making, higher teacher education and professionalism, greater teacher satisfaction and teacher commitment and positive student performance, especially with respect to attitudes toward school and learning.

As an organizational factor, school management also has its own view of the mutual impact of organizational factors on the quality of learning outcomes. Conducting research in Hong Kong's high school education system, Cheng and Mok (2007) found significant correlation between management's influence on employee performance, and employees (who directly participate in students' work) influence on outcomes. 


\subsubsection{School infrastructure}

Dihovični and Krunić (2018) points to the importance of technology in the function of facilitating the learning process and evaluating outcomes. Research shows that school conditions and equipment affect the organizational aspects of the school and the process of education and learning (Murillo \& Román, 2011; Barrett et al., 2019). Brinson (2015) illustrates that student learning success in virtual classrooms is greater than student learning in traditional classrooms, in all categories of learning outcomes (knowledge and understanding, research skills, practical skills, perception, analytical skills and social and scientific communication). Research has shown that there is an impact of electronic media on student outcomes, such as satisfaction and learning efficiency. Classroom equipment and the integration of information and communication technologies into the teaching process which entails the question of the professors' expertise (Gil-Flores et al., 2017). Information and communication technologies (ICTs) are starting to play an increasingly important role in the way we communicate, learn and live (Dihovični \& Krunić, 2018). The challenge is to effectively utilize these technologies in a way that serves the interests of students.

The possibilities of information technologies go towards the application of virtual reality in higher education as well and, accordingly, research was conducted comparing the application and content of learning, as well as the elements that shape virtual content and learning content. It has been observed that learning theories need to be more heavily considered when developing virtual applications in order to make them more relevant to learning outcomes, which will increase the accuracy of simulation (Radianti et al., 2020). Given the fact that mobile devices provide an opportunity to stimulate creativity, research findings confirm that there is significant correlation between creativity and education, indicating the need for teachers to take this into account, in practice. Meaningful learning is significantly influenced by the following factors: location, interconnection of communication channels and the planning of the entire process (Jahnke \& Liebscher, 2020; Stahl et al., 2014; Chen et al., 2018; Jeong et al., 2019).

Recognizing emotions by integrating text and visual channels with users, during work, and their connection to motivation, learning style and understanding of the material. The results indicate the need to make special reference to this aspect, since it significantly deters the quality of learning outcomes and their performance (Yadegaridehkordi et al., 2019).

\subsubsection{Elementary school students' foreknowledge}

Foreknowledge reflects all of the previously acquired knowledge. Klassen and Kim (2019) find that foreknowledge enables students to better understand the course material, to actively participate in the classes and to more easily adopt new knowledge on the basis of existing ones. Therefore, as prior knowledge affects the speed and quality of acquisition of new knowledge, it can also affect the quality of initial knowledge, so it can rightly be considered one of the influential factors.

\subsubsection{Teachers competences}

Teaching quality is always regarded as an important indicator of the quality of education and school effectiveness (Singh, \& Sarkar 2015). A large number of educational research conduct- 
ed using different methodologies, under different educational contexts (Teddlie \& Reynolds, 2000), has shown that some teachers contribute more to their students' progress than others, and that differences in students' educational attainment are the result of classroom processes rather than school variables (e.g., school equipment, school climate).

Based on their research, Klassen and Kim (2019) recognize the need to improve the method of assessing the choice of future teachers and their competencies, in order to improve the outcome of education itself. A similar view was expressed by other authors, such as Atteberry et al. (2015), Darling-Hammond (2010), Jackson et al. (2014), Marks and Moss (2016), and Patterson et al. (2016).

The importance of keeping in mind gender diversity and educational status when creating employee motivation programs is hinted at by authors (Hitka et al., 2017), who state, in light of the aforementioned, that it contributes to employee satisfaction and loyalty, as well as the more efficient fulfillment of business goals and an increase in market competitiveness.

The importance of educators'/teachers' competences in contemporary society is a key issue in a quality education system (Kunter et al., 2013; Long et al., 2014).

\subsubsection{Curriculum content}

The curriculum for quality basic education signifies a wide range of different understandings. The term curriculum refers to programs, program documents or simply parts of school curriculum that relate only to teaching.

Allan (1996) outlines the basic steps in the transition to a curricular concept of outcomebased education that involves defining educational outcomes for knowledge, skills, attitudes, and values that students should possess after completing a particular level of education. Learning outcomes (results, achieved effects) determine the knowledge, skills, attitudes, and values that each student should develop within compulsory elementary education. He states that planning outcomes for higher education are increasingly successful. Monitoring the link between the curriculum and the expected outcomes is considered important, stressing that it is necessary to define outcomes and compare goals and outcomes that are not synonymous. Therefore, the results of learning outcomes are also used as a starting point for the further development of new curricula, thus facilitating the development of information systems in the field of program design that are adapted to the adoption of new curricula.

\subsubsection{Pupils' motivation}

Modern psychology attaches great importance to motivation. One of the most significant problems in teaching is the question: how to motivate, demotivate and/or under-motivate students to learn? Trebješanin (2014) believes that not only power (being able) but also wanting (being motivated) is required for success in learning. Vesić (2003) claims that one of the main tasks for work motivation is finding a strategy for motivating, whereby the given programs must take into account the individual characteristics of people as well as the social and cultural conditions under which they live and work.

Arsić et al. (2011) argue that students' motivation for work can be indirect and a reflection of employees' satisfaction as it is related to teacher productivity and thus the quality of the education system. It is considered that the quality of work of a particular school and its 
success depends to a large extent on the way the school is managed, the quality of teaching, and the type and quality of the processes that take place within the school.

\subsubsection{Quality of the teaching process}

The quality of the educational process can best be achieved and controlled by defining standards of quality for learning outcomes and a systematic control of the achievement of standards. Quality control of education is first and foremost a control of the quality of student learning outcomes upon successful completion of the program (learning outcomes). It should be directly and transparently linked to how students will learn (teaching and teaching materials) and how what they know, understand or know how to do will be verified. Quality measurement also covers processes such as: external evaluation of the school as an institution and its curriculum, following the Rulebook on the Evaluation of the Quality of Work of Institutions (2012), which follows the Rulebook on Quality Standards for Institutions (2012).

\section{Methodology}

The basic idea that influenced this research paper came from the fact that during the management of an educational institution one must insist on the formulation and applicability of such a strategy that should enable the educational institution, in this case, the elementary school, to achieve the best possible success. In this way, the educational/upbringing institution adapts better to its environment and has a greater influence on it. The quality of the strategy involves looking at and learning about the opportunities and weaknesses of the institution.

Quality of the learning outcomes may arise as an indicator of successful management of organizational factors in an educational institution. The aim of the research is to examine management's assessment of the role and importance of the influence of organizational factors on the quality of elementary education, so that the application of the given knowledge enables an increase in the educational level and better learning outcomes through the efficient management of organizational factors.

The modern education system and strategies for long-term management of an educational institution are related to the importance of the influence of organizational factors within the institution itself. This paper analyzes an assessment by managers (school principals) on the impact of organizational factors (ranking by importance), in an elementary school educational-upbringing institution, on the quality of teaching and learning outcomes.

Velazquez et al. (2010) state that not all considered criteria are of the same importance during multi-criteria analyzes, and that each of them has a certain weight in accordance with the significance it achieves. The research implementation plan within this paper can be presented in the following steps: 1 . defining research criteria; 2 . selection of research method; 3. formation of a panel of experts; 4 . collecting expert responses after ranking the criteria according to the assumed impact; 5 . data processing using the selected method; 6 . analysis of the obtained result. Each of the considered organizational factors in the research conducted within this paper can be considered as one of the criteria. The multicriteria method chosen to conduct this research is Step-wise Weight Assessment Ratio Analysis (SWARA), because, 
as Hashemkhani et al. (2018) state, it is able to calculate the weight coefficients of the criteria without taking alternatives into account. A panel consisting of 21 experts has been formed, which will be discussed in more detail in subchapter 2.1. Sample. Expert panel responses are collected and data are processed via the SWARA method using fuzzy numbers to ensure the reliability of the results and solve the problem of subjectivity in the expert responses. Obtained results should provide the possibility to test defined hypothesis H0: There is no difference in the influence of organizational factors in elementary education on the quality of learning outcomes based on the assessments of elementary school principals.

\subsection{Sample}

Principals from 21 elementary schools from the territory of the Novi Sad, the South Bačka District in Serbia, participated in this research. Of these, 11 were male (52.4\%) and 10 were female $(47.6 \%)$, and out of those $28.6 \%$ belonged to the 41 to 50 age categories while $66.7 \%$ belonged to the 51 to 65 age categories. Schools were selected by random sampling, and 35\% of them were surveyed in the cited administration. Principals' opinions are taken into consideration within this paper because they can be considered as leaders and decision makers in the implementation of the reforms within the school system. Data collection was organized in September 2018 and the response rate is $100 \%$.

\subsection{Instruments}

In order to investigate the impact of organizational factors on learning outcomes in elementary education, a questionnaire was designed for principals on the rank of the assessed significance of the stated organizational factor, i.e., its impact on learning outcomes. Organizational factors, that are the subject of this research, are derived from the previous researches of various different authors, who perceived the outcome of learning quality in higher education (Shahjahan \& Torres, 2013; Määttä \& Uusiautti, 2012; Rubio-Alcala et al., 2019). These researches motivated the creation of the questionnaire that consists of 7 factors, which are presented in the Table 1, where the principals were instructed to assign number 7 to the factor of highest importance and number 1 to the factor with the least significance on the quality of learning outcomes.

Table 1. Examined criteria

\begin{tabular}{|l|c|}
\hline \multicolumn{1}{|c|}{ Criteria } & Given rank \\
\hline School management & C1 \\
\hline School infrastructure & C2 \\
\hline Elementary school students' foreknowledge & C3 \\
\hline Teachers' competences & C4 \\
\hline Curriculum content & C5 \\
\hline Pupils' motivation & C6 \\
\hline Quality of the teaching process & C7 \\
\hline
\end{tabular}




\subsection{Step-wise Weight Assessment Ratio Analysis (SWARA) method}

The data were analyzed using the Step-wise Weight Assessment Ratio Analysis (SWARA) statistical method (SWARA) which is one of the more recent Multi-criteria Decision Making MCDM methods (Hashemkhani \& Saparauskas, 2013). It was first presented by Keršuliene et al. (2010). The basic feature of the SWARA method is reflected in its ability to assess the opinions of experts or decision makers on the relationship of criteria of importance in the weighting process (Narayanan \& Jinesh, 2018). Therefore, the backbone of this method is that it enables one to evaluate the opinion of experts on the order of key factors that influence the final decision making in any field. More specifically, this method assigns a weighting to each of the factors or criteria according to which a decision is to be made. In order to arrive at the weighting value, it is necessary to go through several steps, which are described in detail in the work of Aghdaie et al. (2014).

In comparison to other MCDM methods, such as AHP or Shannon's Entropy, it is proven that SWARA has priority (Mardani et al., 2017; Banihabib et al., 2020). Comparing results of AHP and SWARA by ROC value Panahi et al. (2017) find that SWARA technique has a proper accuracy.

\subsection{The calculating procedure for the SWARA method using fuzzy numbers}

The application of fuzzy logic in the calculation of SWARA weights helps to cope with uncertainty (Vatansever \& Akgül, 2019). Fuzzy logic in multi-criteria decision making contributes in making a comprehensive and reasonable decision (Tsaur et al., 2002). The advantage of using fuzzy numbers instead of crisp numbers in the calculations of weighting coefficients using multicriteria methods, in conditions of uncertainty or subjectivity of the answers of a group of experts, is reflected in obtaining more reliable results (Yurdakul \& İç, 2009).

As stated by Brown (1971), the concept of fuzzy sets was introduced by Zadeh in 1965. In practice, experts may face difficulty in providing an accurate assessment due to a lack of knowledge or experience in a particular field, the uniqueness of tasks, or an insufficient basis for comparing the significance of the criteria. To deal with this kind of uncertainty, we can apply triangular fuzzy numbers instead of crisp numbers, as can be see on Figure 1 (Radionovs \& Uzga-Rebrovs, 2017). A fuzzy number is prepared as follows: $\tilde{A}=\left(a_{1}, a_{2}, a_{3}\right)$. This presentation can be interpreted as a membership function:

$$
\mu_{\tilde{A}}(x)=\left\{\begin{array}{lll}
0 & \text { for } \quad x<a_{1} ; \\
\frac{x-a_{1}}{a_{2}-a_{1}} & \text { for } & a_{1} \leq x \leq a_{2} ; \\
\frac{a_{3}-x}{a_{3}-a_{2}} & \text { for } & a_{2} \leq x \leq a_{3} ; \\
0 & \text { for } & x>a_{3} .
\end{array}\right.
$$

At the same time, the parameters of the membership function indicate the smallest possible, expected and the highest possible value (Gani \& Assarudeen, 2012; Živković \& Nikolić, 2016). 


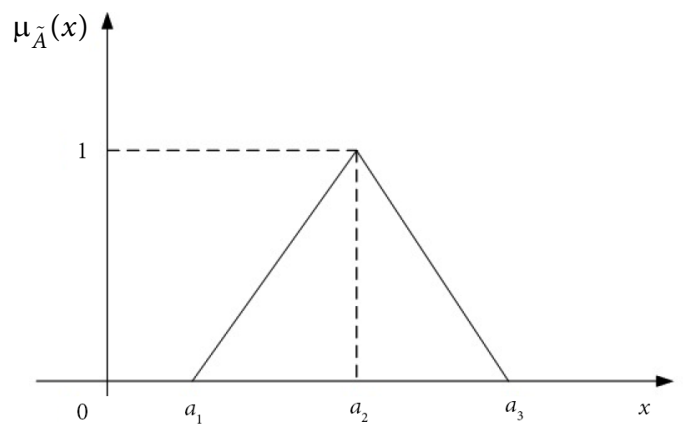

Figure 1. Triangular fuzzy number

The calculation of weighting criteria using the SWARA method begins with decision makers sorting the criteria in descending order, according to the expected significance. Fuzzy numbers are applied in the second step of the SWARA method whereby decision makers determine the comparative importance of the average value $\tilde{s}_{j}$ (Ghorabaee et al., 2018). The other steps of the SWARA method are applied in the same manner as in the procedure without fuzzy numbers, using the following formulas for the calculation of a coefficient $\tilde{k}_{j}$ (2), recalculated weights $\tilde{q}_{j}(3)$ and the final relative weights of the criteria $\tilde{w}_{j}$ (4) (Petrović et al., 2019):

$$
\begin{gathered}
\tilde{k}_{j}=\left\{\begin{array}{ll}
\tilde{1}_{1} & j=1 \\
\tilde{s}_{j}(+) \tilde{1}, & j>1
\end{array} ;\right. \\
\tilde{q}_{j}=\left\{\begin{array}{ll}
\tilde{1}, & j=1 \\
\frac{\tilde{x}_{j-1}}{\tilde{k}_{j},} & j>1
\end{array} ;\right. \\
\tilde{w}_{j}=\frac{\tilde{q}_{j}}{\sum_{k=1}^{n} \tilde{q}_{k}},
\end{gathered}
$$

where $j$ denotes the criterion (Hashemkhani et al., 2018), $\tilde{x}_{j}$ denotes recalculated criteria value and $n$ denotes the number of criteria in the research.

Finally, by defuzzification of the numbers, a final weighting value is obtained for each of the criteria.

\section{Results}

In order to evaluate the impact of organizational factors on the quality of learning outcomes in elementary education, and to learn about the possibilities of successfully managing these factors in order to achieve and maintain high quality of learning outcomes, which ultimately affects the image of the schools themselves, principals defined the ranking criteria. Seven criteria were ranked with seven scores, according to which the significance of the criteria 
was defined. The most important criterion was assigned a score of 7 , as the criterion with the highest level of importance in relation to the quality of learning outcomes. Table 2 shows the rank values for each criterion assigned by the school principals.

Table 2. Rank values for the tested criteria (the meaning of the criteria has been provided under Table 1)

\begin{tabular}{|c|c|c|c|c|c|c|c|}
\hline Principal (decision maker) & $\mathrm{C} 1$ & $\mathrm{C} 2$ & $\mathrm{C} 3$ & $\mathrm{C} 4$ & C5 & C6 & $\mathrm{C} 7$ \\
\hline 1 & 4 & 5 & 2 & 3 & 6 & 1 & 7 \\
\hline 2 & 7 & 5 & 1 & 7 & 4 & 3 & 6 \\
\hline 3 & 2 & 6 & 4 & 3 & 7 & 1 & 5 \\
\hline 4 & 2 & 1 & 5 & 6 & 3 & 4 & 7 \\
\hline 5 & 7 & 2 & 1 & 3 & 6 & 4 & 5 \\
\hline 6 & 2 & 5 & 1 & 6 & 3 & 4 & 7 \\
\hline 7 & 3 & 2 & 1 & 7 & 4 & 6 & 5 \\
\hline 8 & 2 & 6 & 4 & 5 & 1 & 3 & 7 \\
\hline 9 & 1 & 5 & 6 & 4 & 2 & 3 & 7 \\
\hline 10 & 2 & 5 & 1 & 4 & 6 & 3 & 7 \\
\hline 11 & 5 & 3 & 1 & 6 & 4 & 2 & 7 \\
\hline 12 & 6 & 5 & 3 & 2 & 4 & 7 & 1 \\
\hline 13 & 4 & 1 & 7 & 2 & 3 & 6 & 5 \\
\hline 14 & 4 & 5 & 7 & 3 & 1 & 2 & 6 \\
\hline 15 & 6 & 3 & 2 & 4 & 1 & 5 & 7 \\
\hline 16 & 2 & 5 & 3 & 7 & 1 & 4 & 6 \\
\hline 17 & 6 & 2 & 1 & 5 & 3 & 4 & 7 \\
\hline 18 & 1 & 6 & 4 & 7 & 2 & 3 & 5 \\
\hline 19 & 6 & 5 & 1 & 3 & 1 & 2 & 4 \\
\hline 20 & 6 & 5 & 3 & 7 & 2 & 1 & 4 \\
\hline 21 & 4 & 5 & 6 & 3 & 7 & 2 & 1 \\
\hline Mean rank & 3.90 & 4.14 & 3.05 & 4.62 & 3.38 & 3.33 & 5.52 \\
\hline
\end{tabular}

The presented table makes it possible to summarize the principals' estimates, by criteria, and to calculate the arithmetic mean of each of them. Based on the obtained arithmetic mean values, and the first step of the SWARA method, the criteria were ranked from best to worst. The ranking of criteria based on the mean values of the assigned ranks has been presented under Table 3.

Following the previously explained calculation procedure using the fuzzy SWARA method, the comparative significance of the average value $\tilde{s}_{j}$ is performed by comparing each criterion against the previous criterion and assigning to them fuzzy numbers based on the estimated relative importance of one criterion considered in relation to another. After this step, the calculation of the $\tilde{k}_{j}$ coefficient is continued by applying formula (2) in the third step. The fourth step involves calculating the recalculated weight $\tilde{q}_{j}$ using formula (3), while the final relative weights of the criteria $\tilde{w}_{j}$ are obtained by applying formula (4) and defuzzi- 
Table 3. Rank criteria based on mean rank values

\begin{tabular}{|c|c|}
\hline Criteria & Average value \\
\hline C7 & 5.52 \\
\hline C4 & 4.62 \\
\hline C2 & 4.14 \\
\hline C1 & 3.90 \\
\hline C5 & 3.38 \\
\hline C6 & 3.33 \\
\hline C3 & 3.05 \\
\hline
\end{tabular}

fication of triangular fuzzy numbers. The indicated steps of the fuzzy SWARA method have been presented under Table 4.

From Table 4, it can be seen that the final ranking of the criteria in descending order is as follows: C7 (quality of teaching process), C4 (teacher competencies), C2 (infrastructure conditions at school), C1 (school management), C5 (curriculum content), C6 (student motivation), C3 (elementary school students' foreknowledge). This result has been illustrated by a graph in Figure 2 for easier visualization of the estimated impact strengths.

This method contributes to the evaluation of the significance of certain organizational factors in relation to others. Weighting coefficients obtained by applying the fuzzy SWARA method can be used for further calculations in combination with other multi-criteria management decision-making methods that will contribute to improving the quality of learning outcomes.

Based on the results presented in Table 4 and Figure 2, it can be observed that, according to the elementary school principals who took part in this research, the $\mathrm{C} 7$ criterion, i.e., the quality of the teaching process, is the most significant criterion while the $\mathrm{C} 3$ criterion is elementary school students' prior knowledge, is the criterion of least importance. This ranking of criteria shows that management considers that elementary school students' prior knowledge is a factor that does not directly influence the learning outcome itself, by placing the emphasis on the quality of the teaching process, as well as on the competences of the

Final weights

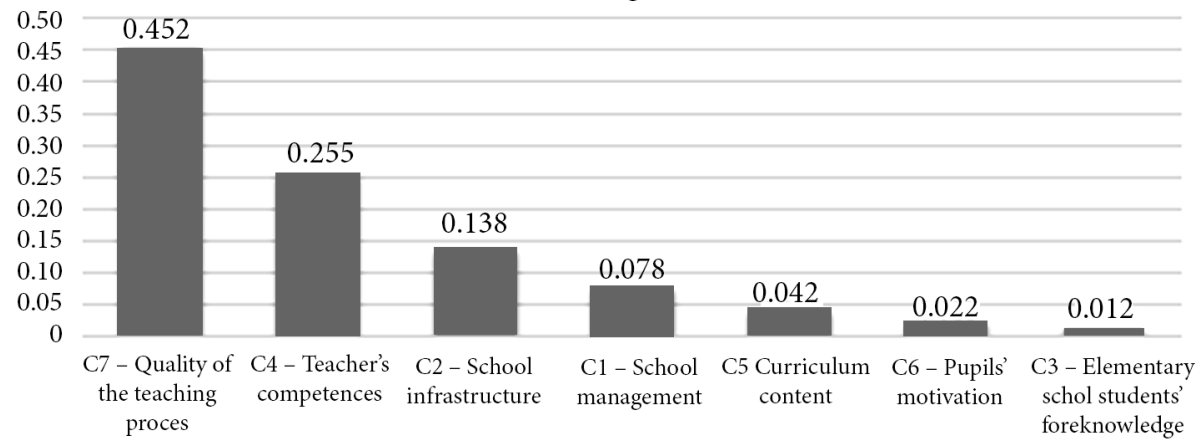

Figure 2. Final weighting coefficients obtained using the fuzzy SWARA method 
employees, probably considering that the staff and a properly implemented teaching process can offset different backgrounds and students' motivation. Such an attitude may also explain why the curriculum is not among the most important criteria, probably respecting the given but retaining the possibility that a good teaching staff with its competencies is a significant mediator between the curriculum, students' prior knowledge and the quality of learning outcomes, by implementing the curriculum (according to the competences available), while taking into account the individuality of children, contemporary educational tendencies in the form of an assertive approach, where circumstances allow, adapting the infrastructure to the teaching units, which will make the content of the course more interesting and thus stimulate the students' active participation in teaching, supporting both critical thinking while taking into account the individuality of each child. The specificity of the ranking of the above criteria is the view that the principals do not see their own role in the organizational factors, that determine the quality of learning outcomes, as dominant although they do affect human resources in a systematic way, which leaves an impression of needing to raise awareness of the importance of taking responsibility for decision making, all in order to improve the quality of student learning outcomes.

Table 4. Final values of fuzzy SWARA weights obtained by number defragmentation

\begin{tabular}{|c|c|c|c|c|c|c|c|c|c|c|c|c|c|c|}
\hline Crit. & \multicolumn{3}{|c|}{$\tilde{s}_{j}$} & \multicolumn{3}{c|}{$\tilde{k}_{j}$} & \multicolumn{3}{c|}{$\tilde{q}_{j}$} & \multicolumn{3}{|c|}{$\tilde{w}_{j}$} & $\begin{array}{c}\text { Final } \\
\text { weights }\end{array}$ \\
\hline C7 & & & & 1 & 1 & 1 & 1 & 1 & 1 & 0.487 & 0.451 & 0.422 & 0.452 \\
\hline C4 & 0.618 & 0.772 & 0.931 & 1.618 & 1.772 & 1.931 & 0.518 & 0.564 & 0.618 & 0.252 & 0.255 & 0.261 & 0.255 \\
\hline C2 & 0.703 & 0.855 & 0.964 & 1.703 & 1.855 & 1.964 & 0.264 & 0.304 & 0.363 & 0.128 & 0.137 & 0.153 & 0.138 \\
\hline C1 & 0.934 & 0.721 & 0.843 & 1.934 & 1.721 & 1.843 & 0.143 & 0.177 & 0.188 & 0.070 & 0.080 & 0.079 & 0.078 \\
\hline C5 & 0.748 & 0.885 & 0.973 & 1.748 & 1.885 & 1.973 & 0.072 & 0.094 & 0.107 & 0.035 & 0.042 & 0.045 & 0.042 \\
\hline C6 & 0.782 & 0.897 & 0.993 & 1.782 & 1.897 & 1.993 & 0.036 & 0.049 & 0.060 & 0.018 & 0.022 & 0.025 & 0.022 \\
\hline C3 & 0.684 & 0.827 & 0.960 & 1.684 & 1.827 & 1.960 & 0.019 & 0.027 & 0.036 & 0.009 & 0.012 & 0.015 & 0.012 \\
\hline Sum & & & & & & & 2.052 & 2.216 & 2.372 & & & & 1.000 \\
\hline
\end{tabular}

\section{Discussion}

Evaluation of the significance of observed organizational factors in elementary education within this paper is conducted using the fuzzy SWARA method. As stated by Mardani et al. (2017) one of the advantages of this method is that there is no need to check consistency of expert assessments.

Elementary school principals took part in this research as members of experts panel. In order to obtain more reliable and accurate results, according to their assessment, fuzzy numbers were incorporated in the calculation using SWARA method. Application of this method leads to the results in the form of weighting coefficients of the oberved organisational factors in elementary education (criteria). The quality of the teaching process is evalauated to be the most significant criterion, with the weighting coefficient of 0.452 . Principals assessed that 
the criterion of elementary school students' foreknowledge is the least influential criterion, with weighting coefficient of 0.012 , when considering the impact on the quality of initial knowledge in primary education in relation to other considered criteria.

The calculation performed by the fuzzy SWARA method yielded a result, in the form of weighting coefficients, which indicates that the influence of each of the organizational factors is different. Accordingly, hypothesis $\mathrm{H} 0$, which reads "There is no difference in the influence of organizational factors in elementary education on the quality of learning outcomes based on the assessments of elementary school principals", is rejected.

The principals attached the highest significance, for the quality of learning outcomes, on the quality of the teaching process as well as on teachers' competencies, thus placing greater emphasis on teacher accountability, while not perceiving their own role as predominantly responsible for the outcomes, rather assessing it as moderately significant. Such an attitude could indicate the need to raise the awareness of school management, i.e., principals, about their own importance and make them assume responsibility for human resources management, without shying away from the responsibility for the possible risks in assessing the success of work results, since school management, with their selection of quality (competent) staff, is inevitably connected with potential school achievement, even over school infrastructure, as employees are those who also take care of the classroom infrastructure, often seeking to refine it in a manner consistent with the teaching units in order to further enhance students' knowledge, as the greater the resulting knowledge the better the ultimate success. A competent staff follows contemporary achievements, educates itself, and applies this knowledge while taking into account the interactive approach to teaching, which makes the content interesting, and its applicability. The foregoing is some of the reasons why principals should not neglect their own importance and responsibility in the aforementioned management of the institution, as well as human resources.

Among the previous research related to the quality of the teaching process, there are those in which the opinions of the students themselves have been taken into account (Nawi et al., 2015; Leon et al., 2017). The obtained results are in accordance with the statements of Araujo et al. (2016) who recognized the impact of the quality of teaching staff and teaching practice in preschool education, with the proviso that in this case a significant impact of this factor was recognized in institutions for the elementary education of students.

\section{Conclusions}

In order to encourage an improvement in the quality of the institutions' work, and raise the quality of learning outcomes, it is necessary to raise awareness of the importance and the mutual influence of certain organizational factors, according to the opinion of school principals (management), as well as the need for their improvement. The organizational factors covered by this research are: school management; school infrastructure; elementary school students' foreknowledge; curriculum content; student motivation; and quality of the teaching process.

Within this paper, the ranking of organizational factors using the fuzzy SWARA method is performed, including an example of the application of multi-criteria methods for solving the problem of improving and optimizing the quality of learning outcomes in elementary 
education. Principals of elementary schools have shown understanding and awareness of the difference in the influence of different organizational factors on the learning of students.

Under conditions of rapid technological development, changes in educational work are continuous, with new upgraded models replacing old ones. Under these conditions, employees play an important role since activities in the educational work are expanded daily, taking into account the active encouragement of student initiatives, risk taking, stimulating curiosity, support for teamwork, humanity and expertise. At the same time, the development of creativity, flexibility and the encouragement of individual development are considered equally significant, at the same time enabling young people to learn life skills. The goals of educational work are the basis for the conception of educational programs, but they are also the essence for determining the criteria for assessing their success.

Through the research results, it was determined that out of seven assessed organizational factors teaching process quality and teaching competences connected with it are important for good quality learning outcomes. As well, that better management of human resources would contribute to a better and more practical organization of the functioning of the basic educational-upbringing institution. Human resources, as such, are the only living organizational resource that, with other organizational resources, work organization, good working conditions, legislative regulation in this field, have a direct and very significant impact on the quality of learning outcomes in elementary education.

Regarding the limitations of the research itself, it can be said that although the impact assessment was mentioned, it cannot be spoken about a real impact because it was a crosssectional study and not a longitudinal study. A longitudinal study could give the answer as to whether the obtained rank of the significance of influences on the quality of learning outcomes is always as stated. Furthermore, the aforementioned administration where the survey was conducted also includes schools that are from smaller towns, and it is assumed that the quality of the research could be raised in the future by examining schools from other regions.

Results about the perceived significance of factors are important for future studies on the management of organizational factors in elementary schools in order to ensure the quality of the outcome knowledge. These empirical research findings may form the basis for some future research in this field, as well as for improving the quality of learning outcomes in educational institutions, at all levels, from pre-school to higher education. Further research into the quality of elementary education should focus on: management competencies, teacher competencies, correlation of school equipment with student success, adaptation of curricula to educational trends, motivation of teachers and school management for better quality work and results. In addition, it would be interesting for future research to examine experts, such as education inspection experts (external evaluators), and see how they would rank the above criteria, since the quality of institutions' performance in accordance with the prescribed standards is part of their job description.

\section{Author contributions}

$\mathrm{VE}$ and SU conceived the study. $\mathrm{AD}$ and $\mathrm{SU}$ were responsible for the design and development of the data analysis. VE was responsible for data collection and $\mathrm{AD}$ was responsible for analysis. GK and NR were responsible for data interpretation. VE wrote the first draft of the article. 


\section{Disclosure statement}

Authors declare that they do not have any competing financial, professional, or personal interests from other parties.

\section{References}

Abdi, K., Mardani, A., Senin, A., Tupenaite, L., Naimaviciene, J., Kanapeckiene, L., \& Kutut, V. (2018). The effect of knowledge management, organizational culture and organizational learning on innovation in automotive industry. Journal of Business Economics and Management, 19(1), 1-19. https://doi.org/10.3846/jbem.2018.1477

Aghdaie, M. H., Hashemkhani Zolfani, S., \& Zavadskas, E. K. (2014). Synergies of data mining and multiple attribute decision making. Procedia - Social and Behavioral Sciences, 110, 767-776. https://doi.org/10.1016/j.sbspro.2013.12.921

Alibabić, Š. (2009). Profesionalizacijamenadžmenta u obrazovanju. Obrazovanje odraslih, IX(2), 9-20.

Allan, J. (1996). Learning outcomes in Higher Education. Studies in Higher Education, 21(1), 93-108. https://doi.org/10.1080/03075079612331381487

Araujo, M. C., Carneiro, P., Cruz-Aguayo, Y., \& Schady, N. (2016). Teacher quality and learning outcomes in kindergarten. The Quarterly Journal of Economics, 131(3), 1415-1453. https://doi.org/10.1093/qje/qjw016

Arsić, M., Urošević, S., Nikolić, Đ., \& Voza, D. (2011, May 26-28). Ispitivanje zadovoljstva zaposlenih u obrazovnim institucijama. In VII Majska konferencija o strategijskom menadžmentu (pp. 390-400). Technical Faculty in Bor, Zaječar, Srbija.

Asfani, K., Suswanto, H., \& Wibawa, A. P. (2016). Influential factors of students' competence. World Transactions on Engineering and Technology Education, 14(3), 416-420.

Atteberry, A., Loeb S., \& Wyckoff, J. (2015). Do first impressions matter? Predicting early career teacher effectiveness. AERA Open, 1(4), 1-23. https://doi.org/10.1177/2332858415607834

Banihabib, M. E., Chitsaz, N., \& Randhir, T. O. (2020). Non-compensatory decision model for incorporating the sustainable development criteria in flood risk management plans. SN Applied Sciences, 2(1), 6. https://doi.org/10.1007/s42452-019-1695-6

Barrett, P., Treves, A., Shmis, T., Ambasz, D., \& Ustinova, M. (2019). The impact of school infrastructure on learning: A synthesis of the evidence. The World Bank. https://doi.org/10.1596/978-1-4648-1378-8

Blume, B. D., Ford, J. K., Baldwin, T. T., \& Huang, J. L. (2010). Transfer of training: A meta-analytic review. Journal of Management, 36(4), 1065-1105. https://doi.org/10.1177/0149206309352880

Brinson, J. R. (2015). Learning outcome achievement in non-traditional (virtual and remote) versus traditional (hands-on) laboratories: A review of the empirical research. Computers \& Education, 87, 218-237. https://doi.org/10.1016/j.compedu.2015.07.003

Brown, J. G. (1971). A note on fuzzy sets. Information and Control, 18(1), 32-39. https://doi.org/10.1016/S0019-9958(71)90288-9

Chang, Y., Leach, N., \& Anderman, E. M. (2015). The role of perceived autonomy support in principals' affective organizational commitment and job satisfaction. Social Psychology of Education, 18(2), 315-336. https://doi.org/10.1007/s11218-014-9289-z

Chen, J., Wang, M., Kirschner, P. A., \& Tsai, C. C. (2018). The role of collaboration, computer use, learning environments, and supporting strategies in CSCL: A meta-analysis. Review of Educational Research, 88(6), 799-843. https://doi.org/10.3102/0034654318791584

Cheng, Y. C. (1994). Principal's leadership as a critical factor for school performance: Evidence from multi-levels of primary schools. School Effectiveness and School Improvement, 5(3), 299-317. https://doi.org/10.1080/0924345940050306 
Cheng, Y. C., \& Mok, M. M. C. (2007). School-based management and paradigm shift in education: An empirical study. International Journal of Educational Management, 21(6), 517-542. https://doi.org/10.1108/09513540710780046

Cruickshank, V. (2017). The influence of school leadership on student outcomes. Open Journal of Social Sciences, 5(9), 115-123. https://doi.org/10.4236/jss.2017.59009

Darling-Hammond, L. (2010). Teacher education and the American future. Journal of Teacher Education, 61(1-2), 35-47. https://doi.org/10.1177/0022487109348024

Dihovični, Dj., \& Krunić, V. (2018). Creating and encrypting e-commerce database for selling mechanical elements. Applied Engineering Letters, 3(3), 85-89. https://doi.org/10.18485/aeletters.2018.3.3.1

Ďurišová, M., Kucharčíková, A., \& Tokarčíková, E. (2015). Assessment of higher education teaching outcomes (Quality of higher education). Procedia-Social and Behavioral Sciences, 174, 2497-2502. https://doi.org/10.1016/j.sbspro.2015.01.922

Fauth, B., Decristan, J., Rieser, S., Klieme, E., \& Büttner, G. (2014). Student ratings of teaching quality in primary school: Dimensions and prediction of student outcomes. Learning and Instruction, 29, 1-9. https://doi.org/10.1016/j.learninstruc.2013.07.001

Gani, A. N., \& Assarudeen, S. M. (2012). A new operation on triangular fuzzy number for solving fuzzy linear programming problem. Applied Mathematical Sciences, 6(11), 525-532. https://doi.org/10.13140/2.1.3405.8881

Gerasymchuk, V. H. (2018). Factors of successful management of organization. Tekstilnaindustrija, $66(2), 52-60$.

Ghorabaee, M. K., Amiri, M., Zavadskas, E. K., \& Antucheviciene, J. (2018). A new hybrid fuzzy MCDM approach for evaluation of construction equipment with sustainability considerations. Archives of Civil and Mechanical Engineering, 18(1), 32-49. https://doi.org/10.1016/j.acme.2017.04.011

Gil-Flores, J., Rodríguez-Santero, J., \& Torres-Gordillo, J. J. (2017). Factors that explain the use of ICT in secondary-education classrooms: The role of teacher characteristics and school infrastructure. Computers in Human Behavior, 68, 441-449. https://doi.org/10.1016/j.chb.2016.11.057

Haapakorpi, A. (2011). Quality assurance processes in Finnish universities: Direct and indirect outcomes and organisational conditions. Quality in Higher Education, 17(1), 69-81. https://doi.org/10.1080/13538322.2011.554311

Hashemkhani Z. S., \& Saparauskas, J. (2013). New application of SWARA method in prioritizing sustainability assessment indicators of energy system. Inzinerine Ekonomika-Engineering Economics, 24(5), 408-414. https://doi.org/10.5755/j01.ee.24.5.4526

Hashemkhani, Z. S. H., Yazdani, M., \& Zavadskas, E. K. (2018). An extended stepwise weight assessment ratio analysis (SWARA) method for improving criteria prioritization process. Soft Computing, 22(22), 7399-7405. https://doi.org/10.1007/s00500-018-3092-2

Hitka, M., Kozubikova, L., \& Potkany, M. (2017). Education and gender-Based differences in employee motivation. Journal of Business Economics and Management, 19(1), 80-95. https://doi.org/10.3846/16111699.2017.1413009

Jackson, C. K., Rockoff, J. E., \& Staiger, D. O. (2014). Teacher effects and teacher-related policies. Annual Review of Economics, 6(1), 801-825. https://doi.org/10.1146/annurev-economics-080213-040845

Jahnke, I., \& Liebscher, J. (2020). Three types of integrated course designs for using mobile technologies to support creativity in higher education. Computers \& Education, 146, 103782. https://doi.org/10.1016/j.compedu.2019.103782

Jeong, H., Hmelo-Silver, C. E., \& Jo, K. (2019). Ten years of computer-supported collaborative learning: A meta-analysis of CSCL in STEM education during 2005-2014. Educational Research Review, 28, 100284. https://doi.org/10.1016/j.edurev.2019.100284

Keršulienè, V., Zavadskas, E. K., \& Turskis, Z. (2010). Selection of rational dispute resolution method by applying new step-wise weight assessment ratio analysis (SWARA). Journal of Business Economics 
and Management, 11(2), 243-258. https://doi.org/10.3846/jbem.2010.12

Klassen, R., \& Kim, L. (2019). Selecting teachers and prospective teachers: A meta-analysis. Educational Research Review Journal, 26, 32-51. https://doi.org/10.1016/j.edurev.2018.12.003

Kokeza, G., Urošević S., \& Radosavljević, D. (2016). Razvoj kompetencija zaposlenihkao element menadžmentaljudskih resursa - saposebnimosvrtomna tekstilnu industriju. Tekstilna industrija, 64(4), 72-83.

Kunter, M., Klusmann, U., Baumert, J., Richter, D., Voss, T., \& Hachfeld, A. (2013). Professional competence of teachers: Effects on instructional quality and student development. Journal of Educational Psychology, 105(3), 805. https://doi.org/10.1037/a0032583

Leon, J., Medina-Garrido, E., \& Núñez, J. L. (2017). Teaching quality in math class: The development of a scale and the analysis of its relationship with engagement and achievement. Frontiers in Psychology, 8, 895. https://doi.org/10.3389/fpsyg.2017.00895

Lin, J. W., Yen, M. H., Liang, J., Chiu, M. H., \& Guo, C. J. (2016). Examining the factors that influence students' science learning processes and their learning outcomes: 30 years of conceptual change research. Eurasia Journal of Mathematics, Science and Technology Education, 12(9), 2617-2646. https://doi.org/10.12973/eurasia.2016.000600a

Long, C. S., Ibrahim, Z., \& Kowang, T. O. (2014). An analysis on the relationship between lecturers' competencies and students' satisfaction. International Education Studies, 7(1), 37-46. https://doi.org/10.5539/ies.v7n1p37

Määttä, K., \& Uusiautti, S. (2012). How to enhance the smoothness of university students' study paths. International Journal of Research Studies in Education, 1(1), 47-60. https://doi.org/10.5861/ijrse.2012.v1i1.16

Mardani, A., Nilashi, M., Zakuan, N., Loganathan, N., Soheilirad, S., Saman, M. Z. M., \& Ibrahim, O. (2017). A systematic review and meta-Analysis of SWARA and WASPAS methods: Theory and applications with recent fuzzy developments. Applied Soft Computing, 57, 265-292. https://doi.org/10.1016/j.asoc.2017.03.045

Marks, A. B., \& Moss, S. A. (2016). What predicts law student success? A longitudinal study correlating law student applicant data and law school outcomes. Journal of Empirical Legal Studies, 13(2), 205-265. https://doi.org/10.1111/jels.12114

Murillo, F. J., \& Román, M. (2011). School infrastructure and resources do matter: analysis of the incidence of school resources on the performance of Latin American students. School Effectiveness and School Improvement, 22(1), 29-50. https://doi.org/10.1080/09243453.2010.543538

Narayanan, A. K., \& Jinesh, N. (2018). Application of SWARA and TOPSIS methods for supplier selection in a casting unit. International Journal of Engineering Research \& Technology, 7(5), 456-458.

Nawi, A., Hamzah, M. I., Ren, C. C., \& Tamuri, A. H. (2015). Adoption of mobile technology for teaching preparation in improving teaching quality of teachers. International Journal of Instruction, $8(2)$, 113-124. https://doi.org/10.12973/iji.2015.829a

Panahi, S., Khakzad, A., \& Afzal, P. (2017). Application of stepwise weight assessment ratio analysis (SWARA) for copper prospectivity mapping in the Anarak region, central Iran. Arabian Journal of Geosciences, 10(22), 484. https://doi.org/10.1007/s12517-017-3290-8

Patterson, F., Knight, A., Dowell, J., Nicholson, S., Cousans, F., \& Cleland, J. (2016). How effective are selection methods in medical education? A systematic review. Medical Education, 50(1), 36-60. https://doi.org/10.1111/medu.12817

Petrović, G., Mihajlović, J., Ćojbašić, Ž., Madić, M., \& Marinković, D. (2019). Comparison of three fuzzy MCDM methods for solving the supplier selection problem. Facta Universitatis, Series: Mechanical Engineering, 17(3), 455-469. https://doi.org/10.22190/FUME190420039P 
Radianti, J., Majchrzak, T. A., Fromm, J., \& Wohlgenannt, I. (2020). A sistematic review of immersive virtual reality applications forhigher education: Design elements, lessons learned, and research agenda. Computers \& Education, 147, 103778. https://doi.org/10.1016/j.compedu.2019.103778

Radionovs, A., \& Užga-Rebrovs, O. (2017). Software tool implementing the fuzzy AHP method in ecological risk assessment. Information Technology and Management Science, 20(1), 34-39. https://doi.org/10.1515/itms-2017-0006

Robinson, V. M., Lloyd, C. A., \& Rowe, K. J. (2008). The impact of leadership on student outcomes: An analysis of the differential effects of leadership types. Educational Administration Quarterly, 44(5), 635-674. https://doi.org/10.1177/0013161X08321509

Rubio-Alcala, F. D., Arco-Tirado, J. L., Fernandez-Martin, F. D., López-Lechuga, R., Barrios, E., \& Pavon-Vazquez, V. (2019). A systematic review on evidences supporting quality indicators of bilingual, plurilingual and multilingual programs in higher education. Educational Research Review, 27, 191-204. https://doi.org/10.1016/j.edurev.2019.03.003

Rulebook on Quality Standards for Institutions. (2012). Official Gazette of the Republic of Serbia, Nos. 7/2011 and 68/2012.

Rulebook on the Evaluation of the Quality of Work of Institutions. (2012). Official Gazette of the Republic of Serbia, No. 9/2012.

Sammons, P., Gu, Q., Day, C., \& Ko, J. (2011). Exploring the impact of school leadership on pupil outcomes: Results from a study of academically improved and effective schools in England. International Journal of Educational Management, 25(1), 83-101. https://doi.org/10.1108/09513541111100134

Shahjahan, R. A., \& Torres, L. E. (2013). A "global eye" for teaching and learning in higher education: A critical policy analysis of the OECD's AHELO study. Policy Futures in Education, 11(5), 606-620. https://doi.org/10.2304/pfie.2013.11.5.606

Singh, R., \& Sarkar, S. (2015). Does teaching quality matter? Students learning outcome related to teaching quality in public and private primary schools in India. International Journal of Educational Development, 41, 153-163. https://doi.org/10.1016/j.ijedudev.2015.02.009

Smiljanić, V. (2013). Razvojna psihologija. Faculty of Philosophy, Belgrade.

Stahl, G., Koschmann, T., \& Suthers, D. D. (2014). Computer-supported collaborative learning. In R. K. Sawyer (Ed.), Cambridge handbook of the learning sciences ( $2^{\text {nd }}$ ed., pp. 479-500). Cambridge University Press. https://doi.org/10.1017/CBO9781139519526.029

Teddlie, C., \& Reynolds, D. (2000). The international handbook of school effectiveness research. Falmer Press.

Trebješanin, B. (2014). Promene u shvatanjudeteta. Journal of Applied Psychology, 7(4), 549-563. https://doi.org/10.19090/pp.2014.4.549-563

Tsaur, S. H., Chang, T. Y., \& Yen, C. H. (2002). The evaluation of airline service quality by fuzzy MCDM. Tourism Management, 23(2), 107-115. https://doi.org/10.1016/S0261-5177(01)00050-4

Vaiciukevičiute, A., Stankevičiene, J., \& Bratčikoviene, N. (2019). Higher education institutions impact on the economy. Journal of Business Economics and Management, 20(3), 507-525. https://doi.org/10.3846/jbem.2019.10156

Vatansever, K., \& Akgül, Y. (2019). Multicriteria decision making models for website evaluation. IGI Global. https://doi.org/10.24327/ijcar.2017.3399.0281

Velazquez, M. A., Claudio, D., \& Ravindran, A. R. (2010). Experiments in multiple criteria selection problems with multiple decision makers. International Journal of Operational Research, 7(4), 413428. https://doi.org/10.1504/IJOR.2010.032419

Vesić, D. (2003). Menadžment ljudskih resursa i kvalitet. Center for Applied Psychology, Belgrade. 
Wahyono, I. (2015). Kompetensi Manajerial Kepala Sekolah Dalam Peningkatan Profesionalisme Guru di SMK Bustanul Falah Kembiritan Genteng Banyuwangi. Jurnal Ar-Risalah, 11(1), 50-64. https://doi.org/10.22373/crc.v1i1.306

Won, S., Anderman, E. M., \& Zimmerman, R. S. (2020). Longitudinal relations of classroom goal structures to students' motivation and learning outcomes in health education. Journal of Educational Psychology, 112(5), 1003-1019. https://doi.org/10.1037/edu0000399

Yadegaridehkordi, E., Binti Mohd Noor, N. F., Bin Ayub, M. N., Binti Affal, H., \& Binti Hussin, N. (2019). Affective computing in education: A systematic review and future research. Computers \& Education, 142, 103649. https://doi.org/10.1016/j.compedu.2019.103649

Yurdakul, M., \& İç, Y. T. (2009). Analysis of the benefit generated by using fuzzy numbers in a TOPSIS model developed for machine tool selection problems. Journal of Materials Processing Technology, 209(1), 310-317. https://doi.org/10.1016/j.jmatprotec.2008.02.006

Živković, Ž., \& Nikolić, Đ. (2016). Osnove matematičke škole strategijs kogmenadžmenta. Technical Faculty in Bor, Serbia. 